\title{
Infrequent Milk Progesterone Measurements in Daughters Enable Bull Selection for Cow Fertility*
}

\author{
T. van der Lende, ${ }^{1,} \dagger$ L. M. T. E. Kaal, ${ }^{2,} \dagger$ R. M. G. Roelofs, ${ }^{1,} \ddagger$ \\ R. F. Veerkamp, ${ }^{3}$ C. Schrooten, ${ }^{2}$ and H. Bovenhuis ${ }^{1}$ \\ ${ }^{1}$ Animal Breeding and Genetics Group, \\ Wageningen University, 6700AH \\ Wageningen, The Netherlands \\ ${ }^{2}$ Holland Genetics, 6802 EB Arnhem, \\ The Netherlands \\ ${ }^{3}$ Division Animal Resources Development, \\ Animal Sciences Group, \\ Wageningen University and Research Center, \\ 8200 AB Lelystad, The Netherlands
}

\begin{abstract}
The interval from calving to first luteal activity (CLA) has been suggested as an unbiased and, therefore, preferable measure for selection on female fertility in dairy cattle. However, measurement of this interval for individual cows is not feasible for reasons of cost and labor associated with the necessary frequent (milk) progesterone measurements. The objective of this study was to test the hypothesis that mean sire progesterone profiles based on individual progesterone measurements of daughters at 3- to 6 -wk intervals have prospects as a measure for female fertility when selecting sires in a progeny testing scheme. In this study, progesterone concentrations were measured in milk samples collected at routinely performed milk recordings during the first $100 \mathrm{~d}$ of lactation of daughters of 20 test bulls. It is demonstrated that a) mean progesterone profiles can be used to calculate the earliest stage of lactation at which at least $50 \%$ of the daughters of a test bull has a milk progesterone level $>3 \mathrm{ng} / \mathrm{mL}$ (indicating luteal activity) and that b) this stage, at which $50 \%$ of the daughters of a bull have an active corpus luteum (CLA50\%), varies largely between test bulls. We conclude that selecting sires based on daughter CLA50\% may improve female fertility.
\end{abstract}

Received December 4, 2003.

Accepted May 27, 2004.

Corresponding author: T. van der Lende; e-mail: tette.vanderlende @wur.nl.

*This study was financed by Holland Genetics, partly through a grant of the Dutch Ministry of Economic Affairs, Project BTS 98194.

$\dagger$ Current address: Division Animal Resources Development, Animal Sciences Group, Wageningen University and Research Center, 8200 AB Lelystad, The Netherlands.

$\ddagger$ Current address: NRS B. V., P.O. Box 454, 6800 AL Arnhem, The Netherlands.
(Key words: bull selection, cow fertility, milk progesterone, first luteal activity)

Abbreviation key: CLA = interval from calving to first luteal activity, CLA50\% = lactation stage at which $50 \%$ of the daughters of a bull have an active corpus luteum, NR56 = nonreturn rate at $56 \mathrm{~d}$ after insemination.

\section{INTRODUCTION}

Over the last decades, fertility in dairy cattle has been declining steadily with increasing milk yields (Royal et al., 2000a). Although many factors may contribute, at least in part, this decline is a correlated response to the ongoing genetic selection for milk yield (Lucy and Crooker, 2001; Pryce and Veerkamp, 2001). It is now generally recognized that direct selection for improved fertility is necessary to contribute to the restoration of fertility or at least counteract a further decline caused by genetic selection for milk yield. Fertility measures based on calving and insemination dates are heavily affected by decisions made by the farmer and, therefore, are not accurate indicators for fertility (Royal et al., $2000 \mathrm{~b})$. In this respect, the interval from calving to first luteal activity (CLA) has been suggested as a preferable measure for fertility (Darwash et al., 1997a,b; Lamming and Darwash, 1998; Royal et al., 2000a; Lamming and Royal, 2001; Royal et al., 2002a). Reported heritability estimates for CLA or transformed CLA are relatively high and vary between 0.14 and 0.28 (Darwash et al., 1997a, 1998; Veerkamp et al., 1998; Royal et al., 2002a,b). Daily measurement of progesterone for individual cows in a progeny testing scheme, where progeny are dispersed among many herds, is not feasible for reasons of cost and labor. Veerkamp et al. (1998) and Darwash et al. (1999) suggested alternative protocols. Veerkamp et al. (1998) hypothesized that mean proges- 
terone profiles of bulls based on monthly individual progesterone measurements of their daughters may have prospects as a measure for female fertility when selecting sires in a progeny testing scheme. The objective of this study was to test this hypothesis in a situation where milk progesterone of daughters of test bulls is measured in samples that are routinely collected for milk recording at 3-, 4-, or 6-wk intervals.

\section{MATERIALS AND METHODS}

\section{Data Collection}

The milk samples for progesterone measurement were collected between October 1999 and November 2000 on dairy farms in the eastern part of The Netherlands during routine milk recording at 3-, 4-, or 6-wk intervals. The milk samples were collected from daughters of 20 Black and White Holstein Friesian test bulls during the first $100 \mathrm{~d}$ of lactation. In total, 4470 milk samples were collected. The samples were preserved with $0.02 \%$ Thimerosal (Sigma) and stored at $4^{\circ} \mathrm{C}$ until assayed for progesterone in duplicate using an enzymelinked immunoassay (Ridgeway Science Ltd., Alvington, Gloucestershire, UK) at the laboratory of the Dutch Animal Health Service (Deventer, The Netherlands). The detection range of the assay was 1 to $50 \mathrm{ng} / \mathrm{mL}$. The intra- and interassay variation coefficients of this assay were 4.2 and $7.5 \%$, respectively (Petit et al., 2002). A milk progesterone concentration $>3 \mathrm{ng} / \mathrm{mL}$ was assumed to indicate the presence of active luteal tissue. The milk progesterone data were linked to pedigree and milk recording data, which resulted in the final data set containing 4090 records on 1687 daughters. Because of the fact that some animals had no milk recording data and some animals were missing in the pedigree file, 380 records had to be deleted from the original data set. The number of daughters per bull varied from 58 to 109 (average $=84$ ), and the number of measurements per bull varied from 137 to 272 (average $=205$ ). This resulted in an average number of measurements per daughter per bull from 2.24 to 2.64 .

\section{Data Analysis}

Before analyzing the data, the actual progesterone measurements were transformed into a binomial trait by assigning the value of one to records with concentrations $>3 \mathrm{ng} / \mathrm{mL}$. All other records were assigned the value of 0 . Based on these binomial values, the fraction of daughters with milk progesterone concentrations $>3$ $\mathrm{ng} / \mathrm{mL}$ was calculated for every lactation stage (d 1 to 100) for each test bull.

To describe, for each test bull, the relationship between stage of lactation and fraction of daughters with a milk progesterone concentration $>3 \mathrm{ng} / \mathrm{mL}$, the Johnson-Schumacher function was used:

$$
P=\alpha \cdot e^{(-\beta / L)}
$$

where $\mathrm{P}$ is the fraction of daughters having a milk progesterone concentration $>3 \mathrm{ng} / \mathrm{mL}$ at lactation stage $\mathrm{L}, \alpha$ is the asymptote of the equation, and $\beta$ is the rate of increase. This function was selected during preliminary analyses from several potentially adequate functions on the basis of the lowest sum of residuals and the distribution of residuals in relation to lactation stage. To estimate the parameters of the function, the NLIN procedure of SAS (1990) was used. The fraction of daughters having a milk progesterone concentration $>3$ $\mathrm{ng} / \mathrm{mL}$ on a particular day of lactation was weighted by the number of measurements on that day.

Pearson product-moment correlations between the lactation stage at which $50 \%$ of the daughters of a test bull had an active corpus luteum (a progesterone level $>3 \mathrm{ng} / \mathrm{mL}$ milk) (CLA50\%) and EBV for a number of milk yield and fertility traits were calculated with the CORR procedure in SAS (1990). The yield traits included were Inet (i.e., the Net Profit Index for milk production, based on EBV for $\mathrm{kg}$ of milk, fat, and protein), milk yield $(\mathrm{kg})$, fat content $(\%)$, fat yield $(\mathrm{kg})$, protein content $(\%)$, and protein yield $(\mathrm{kg})$. The fertility traits included were fertility index (i.e., an index based on days to first service, nonreturn rate at $56 \mathrm{~d}$ after insemination [NR56], and body condition score), days to first service, NR56, and gestation length. All EBV were taken from the November 2001 national evaluations. Number of daughters included per sire ranged between 98 and 180, and reliabilities were approximately 0.93 for production traits and 0.42 for fertility traits.

\section{RESULTS}

In the pooled data for the 20 test bulls, the fraction of daughters with a progesterone concentration $>3 \mathrm{ng} /$ $\mathrm{mL}$ milk was low during the first few weeks of lactation, but increased rapidly between approximately d 20 and 60 (Figure 1). For individual test bulls, the time of commencement of this rapid increase, as well as the rate of increase, differed largely, as can be seen when comparing the fitted curves (Figure 2). The CLA50\% differed largely between test bulls and varied from 25 to $78 \mathrm{~d}$ (average $=41.9 \mathrm{~d}$; SD. $=13.6 \mathrm{~d}$; median $=38$ d). From the 95\% confidence intervals for the curves of the test bulls with the lowest and the highest CLA50\%, it is clear that the curves of these extreme test bulls differ significantly (Figure 3). 


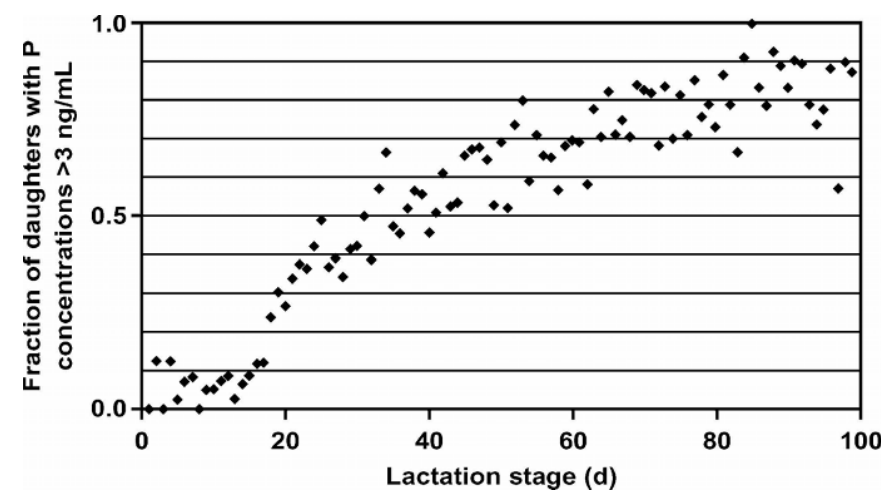

Figure 1. Fraction of daughters of all 20 test bulls with a progesterone $(\mathrm{P})$ concentration $>3 \mathrm{ng} / \mathrm{mL}$ milk in relation to lactation stage $(\mathrm{d}$ 1 to 100$)$.

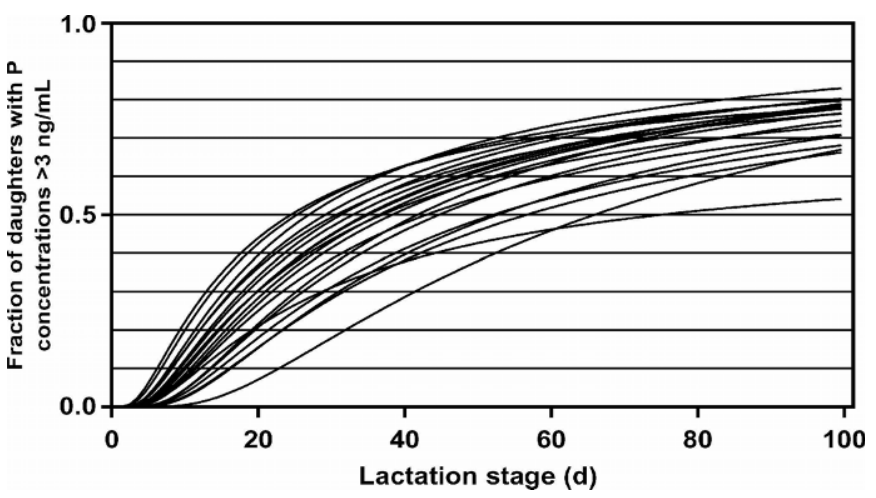

Figure 2. Relationship between lactation stage (d 1 to 100) and fraction of daughters with a progesterone $(\mathrm{P})$ concentration $>3 \mathrm{ng} /$ $\mathrm{mL}$ milk for each of the 20 test bulls. The lactation stage at which $50 \%$ of the daughters of a test bull had a progesterone level $>3 \mathrm{ng} /$ $\mathrm{mL}$ milk varied from 25 to $78 \mathrm{~d}$.

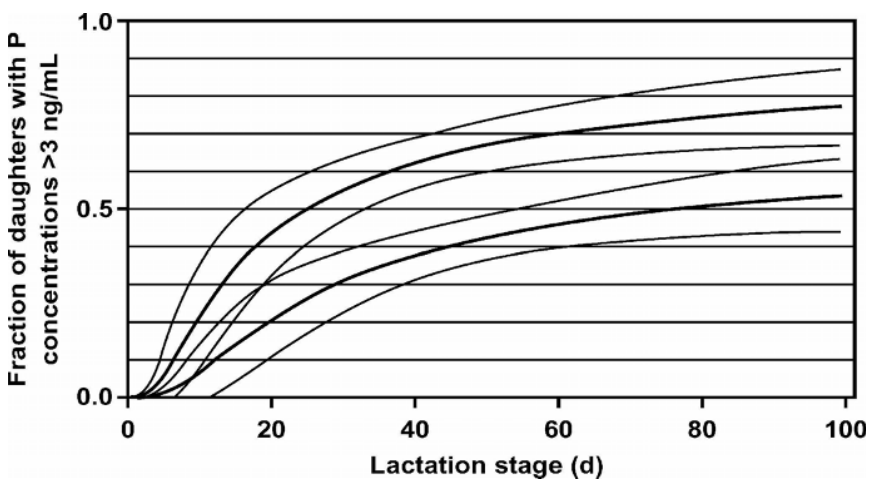

Figure 3. 95\% confidence intervals of the relationship between lactation stage ( 1 to 100 ) and fraction of daughters with a progesterone $(\mathrm{P})$ concentration $>3 \mathrm{ng} / \mathrm{mL}$ milk. Curves shown are for the test bull with the earliest and the test bull with the latest lactation stage ( 25 and $78 \mathrm{~d}$, respectively) at which $50 \%$ of their daughters have a progesterone concentration $>3 \mathrm{ng} / \mathrm{mL}$ milk.
Table 1. Correlations between lactation stage at which $50 \%$ of the daughters of a bull have an active corpus luteum and EBV for production and fertility traits.

\begin{tabular}{lc}
\hline Trait & Correlation \\
\hline Inet $^{1}$ & 0.17 \\
Milk yield (kg) & 0.35 \\
Fat content (\%) & -0.25 \\
Fat yield (kg) & 0.02 \\
Protein content (\%) & -0.21 \\
Protein yield (kg) & 0.30 \\
Fertility index & $-0.73^{* *}$ \\
Days to first service & $-0.63^{* *}$ \\
Nonreturn rate at 56 d & -0.04 \\
Gestation length & 0.13 \\
\hline
\end{tabular}

${ }^{1}$ Inet is the net profit index for milk production, based on EBV for kilograms of milk, fat, and protein.

${ }^{2}$ Fertility index is based on days to first service, nonreturn rate at $56 \mathrm{~d}$, and body condition score.

$* * P<0.01$.

The correlations between CLA50\% and EBV for production and fertility traits are shown in Table 1 . High negative correlations were found for the EBV for fertility index and days to first service, but the correlation with NR56 was virtually zero.

\section{DISCUSSION}

The present study provides evidence that it is feasible to use mean progesterone profiles of bulls based on milk progesterone measurements for many infrequently sampled daughters (for example, at monthly milk recordings) to estimate a reliable CLA measure for progeny-tested bulls. Large variation was observed between test bulls for CLA50\%. Because cows that are already cycling have milk progesterone levels of $<3 \mathrm{ng} / \mathrm{mL}$ for a few days during estrus in each cycle of approximately $21 \mathrm{~d}$, CLA50\% actually indicates the stage of lactation at which at least $50 \%$ of the test bulls' daughters have had their first ovulation followed by luteal activity.

In our study, the actual progesterone values were transformed into a binomial trait. This binomial trait has the advantage that it is easily interpretable compared with the actual progesterone levels, i.e., averages per lactation stage indicate the proportion of animals with an active corpus luteum. Moreover, the fact that the use of the binary trait enables differentiation between test bulls for CLA50\% indicates that relatively simple "yes" or "no" progesterone tests (e.g., a dipstick) may be used instead of more laborious quantitative tests.

Correlations of CLA50\% with EBV for production and other fertility traits can be interpreted as crude estimates of the genetic correlations between these traits. The correlation between CLA50\% and the fertility index currently used in The Netherlands is high (-0.73), indi- 
cating that an earlier commencement of luteal activity is associated with a higher fertility index. However, it also indicates that only approximately $50 \%$ of variation in CLA50\% can be explained by the fertility index. The fertility index is based on the interval from calving to first service, NR56, and body condition score. These traits are either influenced by management decisions or are subjectively scored. Management decisions do not directly affect either CLA (Darwash et al., 1997a, b; Lamming and Darwash, 1998; Royal et al., 2000a; Lamming and Royal, 2001; Royal et al., 2002a) or CLA50\%. Furthermore, several researchers (reviewed by van der Lende, 1998; Butler, 2001; Darwash et al., 2001) have provided evidence that an early onset of ovarian activity after calving increases the chance to get pregnant at the time at which cows are generally inseminated for the first time in practice (i.e., $d 60$ to 80 after calving). This has led to the assumption that a higher number of completed cycles before insemination increases the chance for successful fertilization and/or prenatal survival. The lack of a correlation between CLA50\% and EBV for NR56 in this study and between ln CLA and sire predicted transmitting ability for NR56 in the study of Royal et al. (2003), however, does not seem to confirm this. Although NR56 is a crude estimator of conception rate and early prenatal survival, the very low correlations found in both the present study and the study of Royal et al. (2003) suggest that, at least from a genetic point of view, little relation exists between the time of resumption of ovarian cyclicity and the chance of pregnancy after insemination. A possible explanation for this may be a relatively high genetic correlation between CLA and days to first service, indicating a relatively constant interval between CLA and first service. The correlation of CLA50\% with EBV for days to first service was less than that for the fertility index ( -0.63 vs. -0.73$)$ but was still relatively high. Because a high EBV for days to first service indicates a short interval between calving and first service, this correlation indicates that bulls with a low CLA50\% will have daughters with a short interval between calving and first service. Royal et al. (2003) came to the same conclusion based on the genetic correlation that they had found between ln CLA and the sire predicted transmitting ability for days to first service.

Although the correlations of CLA50\% with milk yield and protein yield were reasonably high $(0.35$ and 0.30 , respectively), they were not significantly different from zero. This may be due to the relatively small number of test bulls included. Based on data for individual cows, Veerkamp et al. (2000) found a genetic correlation between CLA and milk yield of 0.51. For CLA and protein yield, the correlation was 0.48 . In data for individual cows, Royal et al. (2002a) found a genetic correlation between ln CLA and estimated milk yield on d 56 after calving of 0.36 . In the current study, the correlation between CLA50\% and fat yield was 0.02 , whereas Veerkamp et al. (2000), on the level of individual cows, found a genetic correlation between CLA and fat yield of 0.65 . Based on these estimates, it seems realistic to assume that the genetic correlations of CLA50\% with yield traits are in the order of 0.30 to 0.50 . With genetic correlations of this magnitude, successful simultaneous selection for improved milk yield and improved resumption of ovarian cyclicity after calving is feasible, especially if future estimates of the heritability of CLA50\% turn out to be of the same magnitude as the heritabilities reported previously in literature for CLA (i.e., 0.14 to 0.28 [Darwash et al., 1997a, 1998; Veerkamp et al., 1998; Royal et al., 2002a,b]).

\section{CONCLUSIONS}

Individual progesterone measurements in milk samples collected for routinely performed milk recording at 3 - to 6-wk intervals can be used to calculate CLA50\%. This measure for resumption of ovarian cyclicity after calving in female offspring of progeny-tested bulls has good potential as a tool for selecting sires to improve female fertility.

\section{ACKNOWLEDGMENTS}

The authors are grateful to the staff of CR Delta region east for collecting the milk samples and to the Dutch Animal Health Service (Gezondheidsdienst voor Dieren) for analyzing the milk samples for progesterone concentrations.

\section{REFERENCES}

Butler, W. R. 2001. Nutritional effects on resumption of ovarian cyclicity and conception rate in postpartum dairy cows. Occ. Publ. Br. Soc. Anim. Sci. 26:133-145.

Darwash, A. O., G. E. Lamming, and J. A. Woolliams. 1997a. Estimation of genetic variation in the interval from calving to postpartum ovulation of dairy cows. J. Dairy Sci. 80:1227-1234.

Darwash, A. O., G. E. Lamming, and J. A. Woolliams. 1997b. The phenotypic association between the interval to post-partum ovulation and traditional measures of fertility in dairy cattle. Anim. Sci. 65:9-16.

Darwash, A. O., G. E. Lamming, and J. A. Woolliams. 1998. Identifying heritable endocrine parameters associated with fertility in postpartum dairy cows. Proc. Int. Worksh. on Genetic Improvement of Functional Traits in Cattle; Fertility and Reproduction, Grub, Germany, November 23-25, 1997. Interbull. 18:40-54.

Darwash, A. O., G. E. Lamming, and J. A. Woolliams. 1999. The potential for identifying heritable endocrine parameters associated with fertility parameters associated with fertility in postpartum dairy cows. Anim. Sci. 68:333-347.

Darwash, A. O., G. E. Lamming, and M. D. Royal. 2001. A protocol for initiating oestrus and ovulation early post partum in dairy cows. Anim. Sci. 72:539-546. 
Lamming, G. E., and A. O. Darwash. 1998. The use of milk progesterone profiles to characterise components of subfertility in milked dairy cows. Anim. Reprod. Sci. 52:175-190.

Lamming, G. E., and M. D. Royal. 2001. Ovarian hormone patterns and subfertility in dairy cows. Occ. Publ. Br. Soc. Anim. Sci. 26:105-118.

Lucy, M. C., and B. A. Crooker. 2001. Physiological and genetic differences between low and high index dairy cows. Occ. Publ. Br. Soc. Anim. Sci. 26:223-236.

Petit, H. V., R. J. Dewhurst, N. D. Scollan, J. G. Proulx, M. Khalid, W. Haresign, H. Twagiramungu, and G. E. Mann. 2002. Milk production and composition, ovarian function and prostaglandin secretion of dairy cows fed omega-3 fats. J. Dairy Sci. 85:889-894.

Pryce, J. E., and R. F. Veerkamp. 2001. The incorporation of fertility indices in genetic improvement programmes. Occ. Publ. Br. Soc. Anim. Sci. 26:237-249.

Royal, M. D., A. O. Darwash, A. P. F. Flint, R. Webb, J. A. Woolliams, and G. E. Lamming. 2000a. Declining fertility in dairy cattle: Changes in traditional and endocrine parameters of fertility. Anim. Sci. 70:487-501.

Royal, M., G. E. Mann, and A. P. F. Flint. 2000b. Strategies for reversing the trend towards subfertility in dairy cattle. Vet. J. 160:53-60.

Royal, M. D., A. P. F. Flint, and J. A. Woolliams. 2002a. Genetic and phenotypic relationships among endocrine and traditional fertility traits and production traits in Holstein-Friesian dairy cows. J. Dairy Sci. 85:958-967.

Royal, M. D., J. E. Pryce, J. A. Woolliams, and A. P. F. Flint. 2002b. The genetic relationship between commencement of luteal activity and calving interval, body condition score, production, and linear type traits in Holstein-Friesian dairy cattle. J. Dairy Sci. 85:3071-3080.

Royal, M. D., E. Wall, and A. P. F. Flint. 2003. The genetic relationship between interval to commencement of luteal activity postpartum and UK national fertility proofs for dairy cattle. Page 54 in Proc. Br. Soc. Anim. Sci. Annu. Mtg., York, UK.

SAS/STAT. User's Guide. 1990. SAS Inst., Inc., Cary, NC.

van der Lende, T. 1998. Physiological aspects of reproduction and fertility in dairy cows. Proc. Int. Worksh. on Genetic Improvement of Functional Traits in Cattle; Fertility and Reproduction, Grub, Germany, November 23-25, 1997. Interbull. 18:33-39.

Veerkamp, R. F., J. K. Oldenbroek, H. J. van der Gaast, and J. H. J. van der Werf. 2000. Genetic correlation between days until start of luteal activity and milk yield, energy balance, and live weights. J. Dairy Sci. 83:577-583.

Veerkamp, R. F., J. K. Oldenbroek, and T. van der Lende. 1998. The use of milk progesterone measurements for genetic improvement of fertility traits in dairy cattle. Proc. Int. Worksh. on Genetic Improvement of Functional Traits in Cattle; Fertility and Reproduction, Grub, Germany, November 23-25, 1997. Interbull. 18:62-67. 